\title{
Os esquemas de contraponto na música brasileira do Antigo Regime: o caso dos Seis Responsórios Fúnebres de João de Deus de Castro Lobo
}

\author{
Márcio Leonel Farias Reis Páscoa (Universidade do Estado do Amazonas, Manaus, Amazonas, Brasil) \\ marciopascoa@gmail.com
} Guilherme Aleixo da Silva Monteiro (Universidade do Estado do Amazonas, Manaus, Amazonas, Brasil) guidomonte@hotmail.com

\begin{abstract}
Resumo: O presente artigo demonstra o uso de esquemas de contraponto (schematae) pertencentes à teoria musical em voga no período compreendido entre o século XVIII e início do XIX, o chamado Estilo Galante, tais como apresentados por Robert Gjerdingen nos 6 Responsórios Fúnebres de João de Deus de Castro Lobo (1794-1832), de modo a oferecer comprovante de que um sistema teórico-prático de formação e criação musical de origem napolitana alcançou o Brasil.

Palavras-chave: Schemata; Música Brasileira; Castro Lobo; Musicologia; Teoria Musical.
\end{abstract}

The counterpoint schemata in the Brazilian music of Ancient Regime: the case of six Tenebrae Responsories by João de Deus de Castro Lobo

Abstract: This paper shows the schematae belonging to the musical theory in vogue in the period between the eighteenth and early nineteenth centuries, the so-called Galante Style, as presented by Robert Gjerdingen in the six responsories of João de Deus de Castro Lobo (1794-1832), in order to offer proof that a theoretical-practical system of formation and musical creation, of Neapolitan origin, reached Brazil.

Keywords: Schemata; Brazilian music; Castro Lobo; Musicology; Musical theory.

\section{Introdução}

Em fins de 2007 saia à luz o livro Music in the galant style, trabalho de três décadas de pesquisa de Robert Gjerdingen sobre os esquemas compositivos presentes na produção musical de todo o século XVIII e parte significativa do XIX. As schematae, como passaram a chamar os esquemas, já haviam sido objeto de sua tese doutoral em 1984. Neste meio tempo, até a elaboração do premiado trabalho publicado pela Oxford University Press, foi sendo colmatada sua pesquisa com as inequívocas relações que Gjerdingen estabeleceu com o processo de educação musical vigente no período de abrangência de seu estudo, em que despontam os fatores cognitivos, a indissolúvel relação entre teoria e prática da música, a forte dependência da retórica (inclusive musical) e uma abordagem culturalista, que excedem a mera história da teoria musical. Ficava assim explicitada a relação da composição com a atividade prática e psicopedagógica, dando maior sentido não só no campo das análises, mas também da interpretação da música, tendo por foco a origem napolitana destes acontecimentos, os quatro conhecidos conservatórios da capital partenopea.

Outros trabalhos o sucederam, sem exceder o que já havia sido exposto por Gjerdingen. Sanguinetti (2012) concentrou-se no que chamou a Arte do Partimento (um baixo dado sobre o qual se desenvolvem estruturas de contraponto e as suas possibilidades de uso), enquanto Thomas Christensen escreveu livros (alguns como reunião de artigos) sobre história da música com foco sobre o Iluminismo e o pensamento alemão, tecendo certa transversalidade com a matriz italiana observada por Gjerdingen e Sanguinetti. Mais recentemente, como consequência do trabalho de Gjerdingen, surgiram as contribuições de John A. Rice na tentativa de identificar mais esquemas de contraponto em uso no período em pesquisa, sem, entretanto, examinar o mesmo corpus musical do primeiro autor e o fazer necessariamente em publicações científicas. E o trabalho de Peter Van Tour, cujo doutorado de 2015 foi arguido por Gjerdingen, a quem segue na missão de catalogar e indexar 
fontes primárias do partimento e do solfeggio, sem, no entanto, oferecer qualquer nova abordagem interpretativa para o fenômeno e sem mesmo se preocupar com o nível de complexa abrangência dos eventos; a sua atenção para com as publicações dos cadernos de partimento de autores do passado é uma explicitação do que rezava Music in the Galant Style e, seu trabalho, somado a de novos expoentes dessa área, como o caso de Vasily Byros, que tem se concentrado em aspectos linguísticos (retórica, tópicas, colostrução), deve permitir a continuidade dos estudos nesse campo e um melhor entendimento do assunto.

Parece ser muito oportuno que se observe então o alcance geográfico da metodologia pedagógica de caráter teórico-prática que formava um músico, a partir dos modelos fundados pelos conservatórios napolitanos, de vez que os jovens estudantes, de tenra idade, rapidamente adquiriam habilidades que os permitiam transitar para o profissionalismo; não há um ponto de virada neste quesito, como é o caso do modelo conservatorial tecnicista norte europeu de Oitocentos, com seus mecanismos de homologação. Crianças órfãs em Nápoles se tornavam músicos habilidosos e criativos através de um processo gradual de emancipação e não raramente já integravam atividades profissionais de alto nível antes de chegarem à idade limite para deixarem a instituição que os acolhera em regime de internato, por volta dos 17 anos. Isso inclusive explica fenômenos como Pergolesi, que só viveu 26 anos e produziu em alta qualidade, e que se repetiram ao longo de muitas décadas.

Na ausência de cadernos de partimento ou solfeggio em quantidade necessária para vincular tais práticas no ambiente brasileiro, surgem opcionalmente duas estratégias para tentar verificar se tais modelos foram aqui implementados: a inevitável comparação com as fontes portuguesas do período, uma vez que o Brasil integrava a mesma unidade político-administrativa e cultural que Portugal e dele muito recebeu; e a análise musical em que constem os expedientes compositivos que evidenciam-se como vestígios históricos inequívocos desta influência, mormente aqui no caso deste artigo as schematae. Deve-se alertar que nem a alusão por afinidade é prova cabal, dentro de paradigmas científicos mais estruturantes, nem o uso por si só de schematae leva a crer que todo o restante do panorama cultural napolitano foi aqui copiado, ou o foi em generalidade.

Entretanto, como o próprio uso de schematae permite concluir, a norma é muito menos frequente que suas variantes, como o terá reafirmado várias vezes Gjerdingen (sobretudo no V Simpósio de Música Ibero-Americana realizado em maio de 2018 em Manaus), mostrando inclusive que a norma tem por costume aparecer em pontos de destaque e as variantes se multiplicam ao longo de toda a estrutura compositiva (um movimento, uma peça, um opus). Isto porque o conceito das schematae, à luz do schematon grego, tem por função compreender frases e conteúdos de modo a comunicar ideias, temas e figuras. As figuras alteram a norma para desenvolver o assunto (tópico) e com isso alteram também o schema.

Não havendo até o momento nenhum artigo em periódico nacional indexado sobre obra de grande dimensão de compositores brasileiros em que se tenha estabelecido a prática recorrente das schematae em seu bojo, pareceu-nos passo importante para o estudo adequado de nossa produção musical verificar a diversidade do uso de tais esquemas num trabalho complexo e maduro, para compositor e meio produtivo, como é o caso dos Seis Responsórios Fúnebres, de João de Deus de Castro Lobo; ele mesmo um virtuoso que muito cedo esteve à frente de orquestra de ópera, do serviço organístico de uma Sé importante, assim como no provimento de composição musical para diversos momentos.

\section{Aspectos históricos e contexto criativo}

Os estudos acerca da música europeia setecentista apontam para uma prática amplamente disseminada no Ocidente europeu de procedimentos composicionais centrada no 
que se denomina de partimenti, ou baixos instrucionais. Detectáveis a partir da prática pedagógica dos conservatórios de Nápoles, os partimenti eram, segundo Gjerdingen (2007, p. 465), linhas de baixo a serem executadas pela mão esquerda do estudante em um instrumento de teclas, sendo adicionadas às mesmas acordes ou vozes contrapontísticas com a mão direita. Assim, sabidas as suas finalidades pedagógicas, é fácil inferir que os partimenti possuíam níveis de dificuldade variados, desde formulações elementares, para os não suficientemente iniciados, até intrincadas possibilidades, destinadas aos mais proficientes músicos para finalidades diversas e não só formativas.

A paulatina familiarização com este procedimento composicional estimulou os estudantes a memorizarem pequenas fórmulas musicais (schematae) que melhor respondessem às situações peculiares de um dado partimento. Por meio deste exercício de memorização as schematae tiveram seu primeiro delineamento, passando a constituir um repertório bem assimilado de formulações musicais diversificadas, compiladas no que à época se denominou zibaldone. ${ }^{1}$ Tais schematae podem ser definidos como esquemas de contraponto, ou ainda padrões harmônico-contrapontísticos, tais como descritos a partir do trabalho pioneiro de Robert Gjerdingen (1984; 2007) e acrescido de contribuições posteriores, e ainda em curso, das quais destacam-se Sanguinetti (2012), Byros (2014), Rice (2014; 2016), Van Tour (2015) e Mitchell (2016). Assim como Gjerdingen não se prende em definir o termo porque teme uma simplificação indesejada (GJERDINGEN, 2007, p. 11), ele foca, principalmente, em demonstrar o alcance do conceito para proporcionar sua compreensão naquilo que é seguido pelos demais autores citados. O que tem importado é a busca por observar práticas e conseguir identificar um número ainda mais vasto de schematae ou sua implicação retórica, sobretudo com a Teoria das Tópicas (BYROS, 2014)

Análises diversas, propostas por tais autores, têm mostrado um alcance notável da música de matriz peninsular italiana do século XVIII sobre quase toda a produção musical ocidental, revelando se tratar da orientação analítica mais adequada à compreensão das estruturas musicais elaboradas por muitos compositores de nacionalidades diferentes, mas unidos por características pan-europeias.

Tal capilaridade da música, que se convencionou chamar de Galante (por causa do galant style) ${ }^{2}$ por toda a Europa durante o século XVIII e princípios do século XIX, permite aludir que seus modelos composicionais tenham cruzado o Atlântico, uma vez que já se conhece bem sobre os usos do baixo contínuo na produção musical portuguesa do período (TRILHA NETO, 2011).

Assim sendo, é aliciante recorrer a uma análise de tal natureza sobre a produção brasileira do chamado Antigo Regime, que não sendo apenas o Período Colonial, inclui a época do reinado de Pedro I, uma vez que esse governante herdou e deu continuidade a estruturas artísticas, especialmente musicais, de seus antepassados, bem como a aspectos de gosto e sociabilidade.

O caso que aqui aparece defendido como pertinente é o conjunto de Seis Responsórios Fúnebres escrito por João de Deus de Castro Lobo (1794-1832) nos seus últimos anos de vida, período limítrofe na viragem de épocas do Brasil. Castro Lobo nasceu em Vila Rica, filho mais velho de um músico chamado Gabriel de Castro Lobo, motivo pelo qual muito cedo na vida já estava militando na profissão. Aos 17 anos, em 1811, já ia contratado como regente em uma orquestra de 16 músicos na Casa da Ópera de sua cidade natal; em 1812 era peticionário ao lado de diversos músicos pela confraria de Santa Cecília na mesma cidade; entre 1818 e 1826 manteve contrato como organista e compositor na Ordem Terceira de Nossa Senhora do Monte do Carmo, em paralelo com trabalhos semelhantes para a concorrente ordem terceira da penitência franciscana; por fim, foi mestre de capela da Catedral de 
Mariana de 1825 até sua morte (CASTAGNA, 2012, p. 12). Havendo se ordenado eclesiástico após processo iniciado em 1820, que deve ter sido concluído 4 ou 5 anos depois, Castro Lobo deixou não mais que quatro dezenas de obras, quase todas religiosas. O total delas deve ter sido muito maior, não se pode estimar quanto, posto que se destruíram muitas de suas partituras por estarem no seu espólio pessoal; o padre faleceu vitimado pela sífilis nos primeiros dias de 1832 (CASTAGNA, 2012). Sabe-se a data de composição dos Seis Responsórios ${ }^{3}$ como sendo a última obra, elaborada em 1831 ou talvez desde um pouco antes, por causa da sua incompletude (deveriam, segundo a liturgia, ser nove responsórios para as matinas de defuntos), mas sobretudo pelo testemunho de um de seus primeiros biógrafos:

Depois de haver concluído o Sexto Responsório e encetado o Sétimo, assentado debaixo de anosas jaboticabeiras, que ainda se conservam junto ao prédio onde residia há pouco o insigne homem de letras e mavioso poeta Alfonsus Guimarães, ouviu a execução dos que estavam arrematados e, voltando para o interior dos seus aposentos, profetizou com lágrimas o remate de seus dias: "A minha missão está completa, mas incompletos ficam os Responsórios”. (PIMENTA, 1911 apud CASTAGNA, 2012, p. 19)

A estruturação dos responsórios segue a tradição e vai formalmente da seguinte maneira: para os Responsórios I, II, IV e V configuram-se as seções $\mathbf{R}_{\mathbf{a b}} \mathbf{V} \mathbf{R}_{\mathbf{b}}$, ou seja, em um responso com dois períodos musicais distintos, um verso e um repetendum - representado pelo segundo período do responso; já para os Responsórios III e VI por ser destinada ao encerramento de uma lição, possui a estrutura $\mathbf{R}_{\mathbf{a b}} \mathbf{V}_{\mathbf{1}} \mathbf{R}_{\mathbf{b}} \mathbf{V}_{\mathbf{2}} \mathbf{R}_{\mathbf{b}}$. Assim, tem-se um responso com dois períodos, o primeiro verso, o repetendum, o segundo verso, que atua como substituto à doxologia, contendo o mencionado texto Requiem æternam [...] e, finalmente, o segundo repetendum.

O exame de identificação das schematae mostrou uso abundante de quase todas as elaborações conhecidas pela reconstituição teórico-musicológica até o momento. Elas passam a ser consideradas a partir daqui.

\section{Análise de Schematae: variedade de incidências}

A schemata Do-Ré-Mi gozou de grande prestígio entre os compositores galantes para abertura de diversas obras. Como o próprio nome sugere, esta schemata dá ênfase aos graus escalares da melodia (1-2-3, ou seja, Dó, Ré, Mi), sendo apoiados por um baixo que repousa geralmente sobre os graus 1-7-1 ou 1-5-1. Gjerdingen (2007) dá vários exemplos dela e em Castro Lobo o esquema aparece diversas vezes, obtendo para exemplo aqui o que segue abaixo.

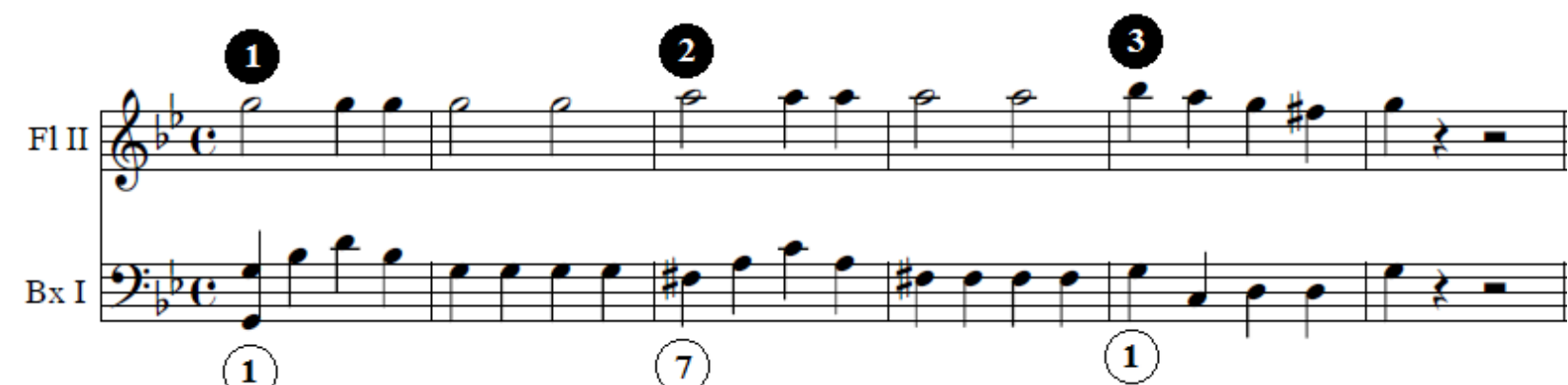

Exemplo 1 - Schemata Do-Ré-Mi: Responsório II, Tu eis, Domine, dona requiem, c. 13-18.

Também uma schemata muito comum em aberturas de frase e movimentos de peças, a Romanesca, vai exemplificada abaixo na obra de Castro Lobo como uma das raras 
inserções na música do mineiro, talvez porque a Romanesca seja uma das mais antigas em uso àqueles dias e já tivesse conhecido seu auge.

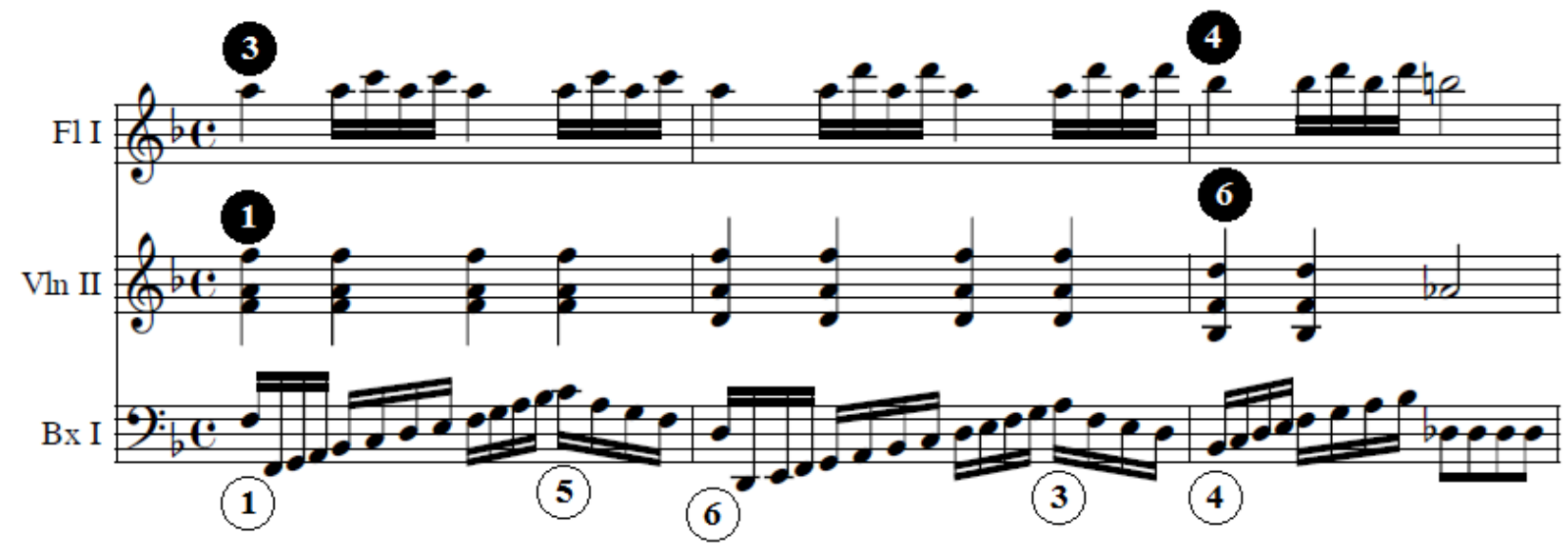

Exemplo 2 - Schemata Romanesca/ Terças Descendentes: Responsório I, Credo quod redemptor meus, c. 12-14.

Esta schemata, segundo Gjerdingen (2007, p. 78), é uma das mais recorrentes para a abertura de movimentos em uma peça galante, embora em Castro Lobo ela apareça no meio da estrutura. Dentre suas principais características, possui um baixo que pode progredir por saltos - possibilidade bastante corriqueira durante o século XVII e princípios do século XVIII (GJERDINGEN, 2007, p. 35): 1-5-6-3-4 ou em variantes de 1-7-6-5-4-3. O seu contraponto melódico transita do primeiro ao quinto grau, ou ainda para a oitava, à medida que 0 baixo desce os graus acima mencionados.

A schemata, tida como um dos principais elementos subsequentes aos esquemas harmônico-contrapontísticos de abertura, como os citados acima, chamada Prinner, ${ }^{4}$ segundo Gjerdingen (2007, p. 45-46), era uma elegante resposta à Romanesca e ao Do-Ré-Mi, por exemplo, e a escolha predileta dos compositores galantes para o fim de inúmeras elaborações. Tal schemata figura bastante vezes na obra Castro Lobo, possuindo como características primordiais uma linha de baixo descendente sobre os graus 4-3-2-1, enquanto a melodia se encaixa em terças superiores, ou seja 6-5-4-3.

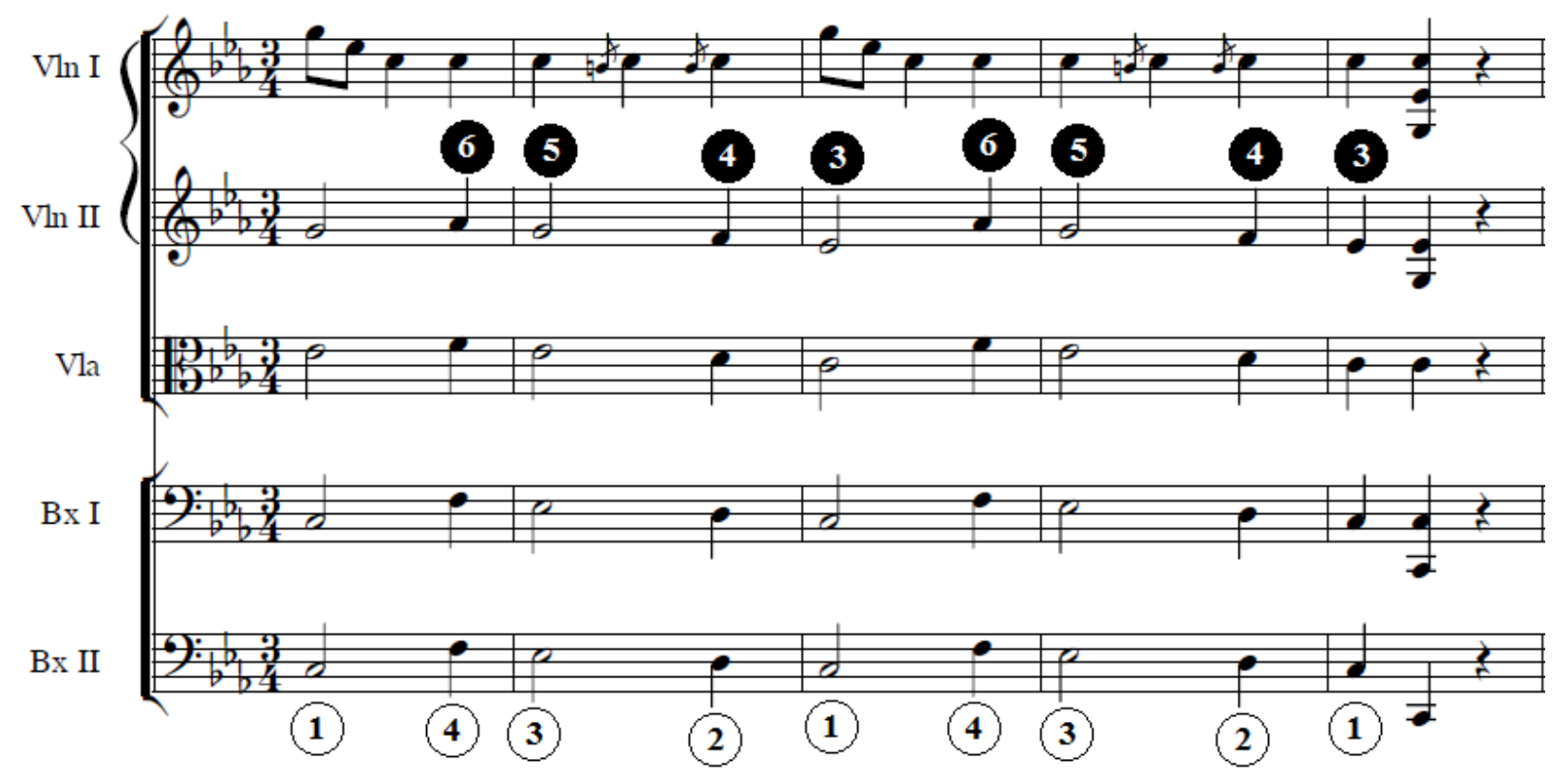

Exemplo 3 - Schemata Prinner: Responsório V, Miserere mei, c. 14-18. 
Castro Lobo utilizou o esquema acima para simular a finalização de frases, sem necessariamente ser o fim de movimentos. Entre suas particularidades é destacável o fato de a melodia ocorrer em uma voz interna, neste caso no violino II, corroborando assim com a maleabilidade que os esquemas harmônico-contrapontísticos possuem. Quanto à sua costumeira atuação como schemata de resposta, o excerto exposto é verificado no início do segundo período do responso, dando início a um movimento contrastante, mais movido em relação ao seu precedente. Assim, em larga escala, temos um Prinner que encabeça uma resposta às schematae presentes no primeiro período do responso.

Três schematae destinadas ao encaminhamento ou desenvolvimento de estruturas musicais já existiam teorizadas no século XVIII por Joseph Riepel (1709-1782): a Fonte, o Monte e a Ponte. A Fonte foi desde o início considerada como uma das mais importantes schematae, na qual um jovem estudante de composição deveria esforçar-se para jamais esquecê-la (IDEM, p. 61). Possui sentido análogo àquele de sua imagem, em que os eventos da mesma - considerados aos pares - sucedem-se em sentido descendente, provocando movimentação por grau conjunto. A particularidade que se observa aqui é que o primeiro evento trata de uma formação triádica menor e no segundo uma tríade maior completando a schemata.

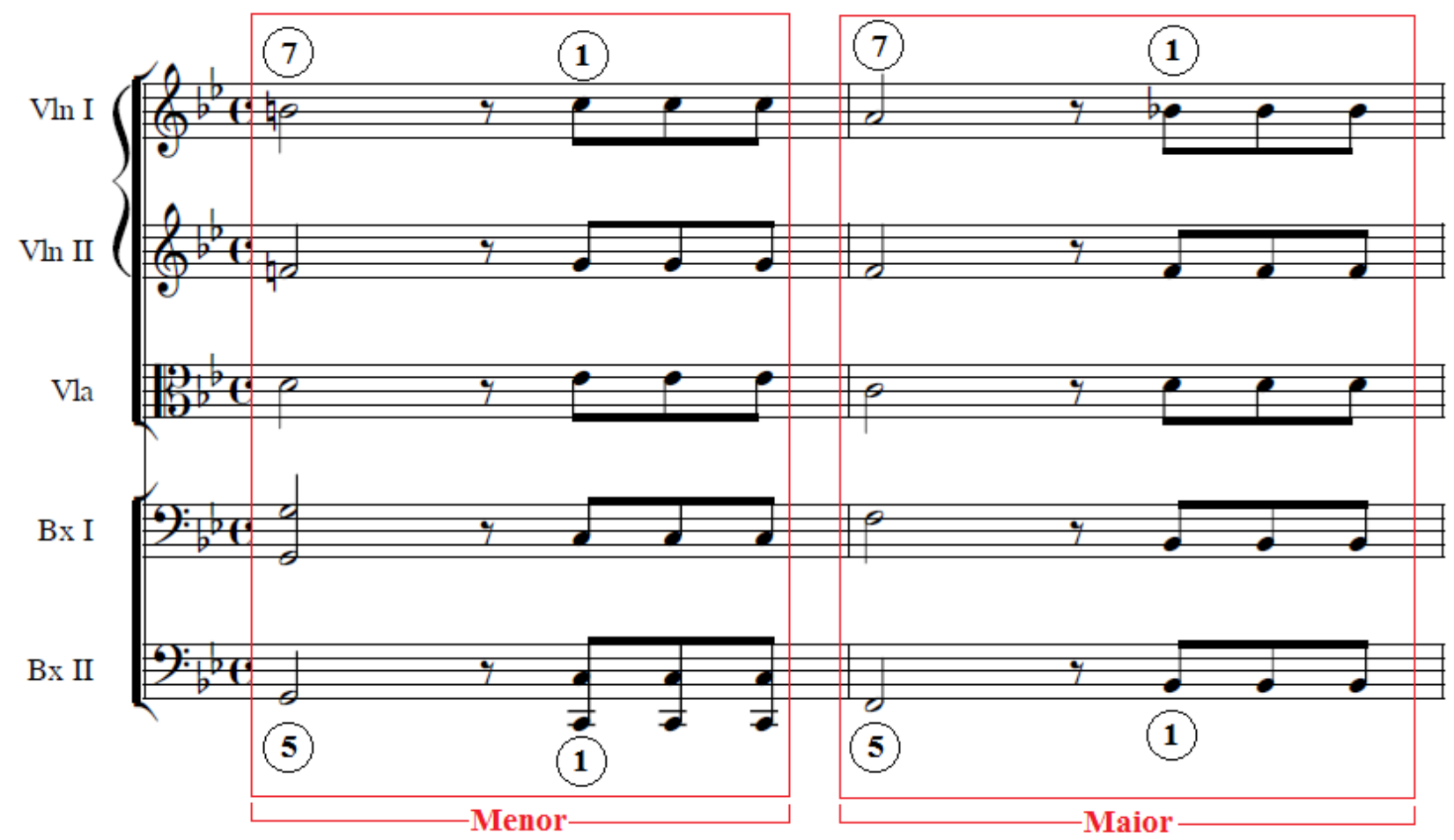

Exemplo 4 - Schemata Fonte: Responsório II, Qui Lazarum resuscitasti, c. 8 e 9.

Castro Lobo valeu-se de muitas variantes desta schemata, como no exemplo acima, onde o baixo 7-1 está na voz superior da estrutura e o comum encaminhamento melódico do quinto ao primeiro grau foi para a voz do baixo; ou ainda no exemplo visto a seguir, onde o esquema apresenta-se nas vozes internas da estrutura e está ornamentado por arpejo: 


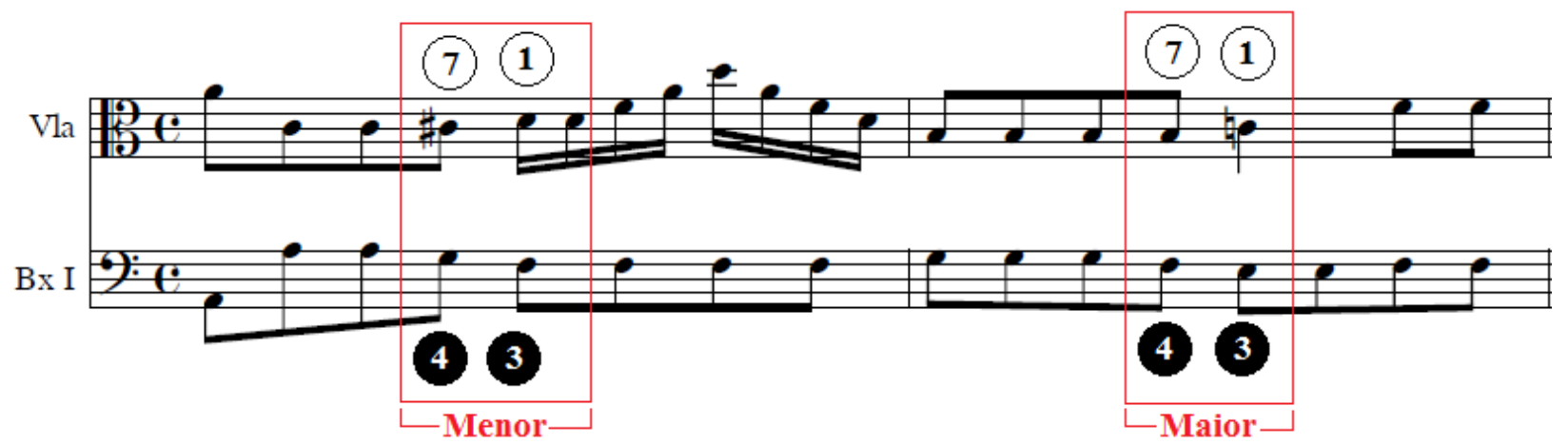

Exemplo 5 - Schemata Fonte: Responsório IV, Memento mei Deus, c. 5 e 6.

A segunda schemata citada por Riepel, e que Gjerdingen evidencia seu largo uso do século XVIII até o XIX, é o Monte. Igualmente à Fonte, esta schemata possui sentido análogo à representação imagética que a fundamenta, operando também por pares de eventos. No entanto, em termos musicais, seu funcionamento se dá em sentido ascendente, podendo lograr também mais de dois pares de eventos em sua apresentação. Outra notável diferença diz respeito à qualidade harmônica desses eventos, pois, ao contrário da Fonte - em que a progressão entre os mesmos se dá sempre na forma Menor $\rightarrow$ Maior (IBID., p. 90) - o Monte pode progredir em diversas combinações: Menor $\rightarrow$ Menor; Menor $\rightarrow$ Maior; Maior $\rightarrow$ Maior; e Maior $\rightarrow$ Menor. Curiosamente, Castro Lobo não foi tão pródigo no uso deste tipo de esquema de contraponto nesta obra, como seus predecessores europeus do período clássico.

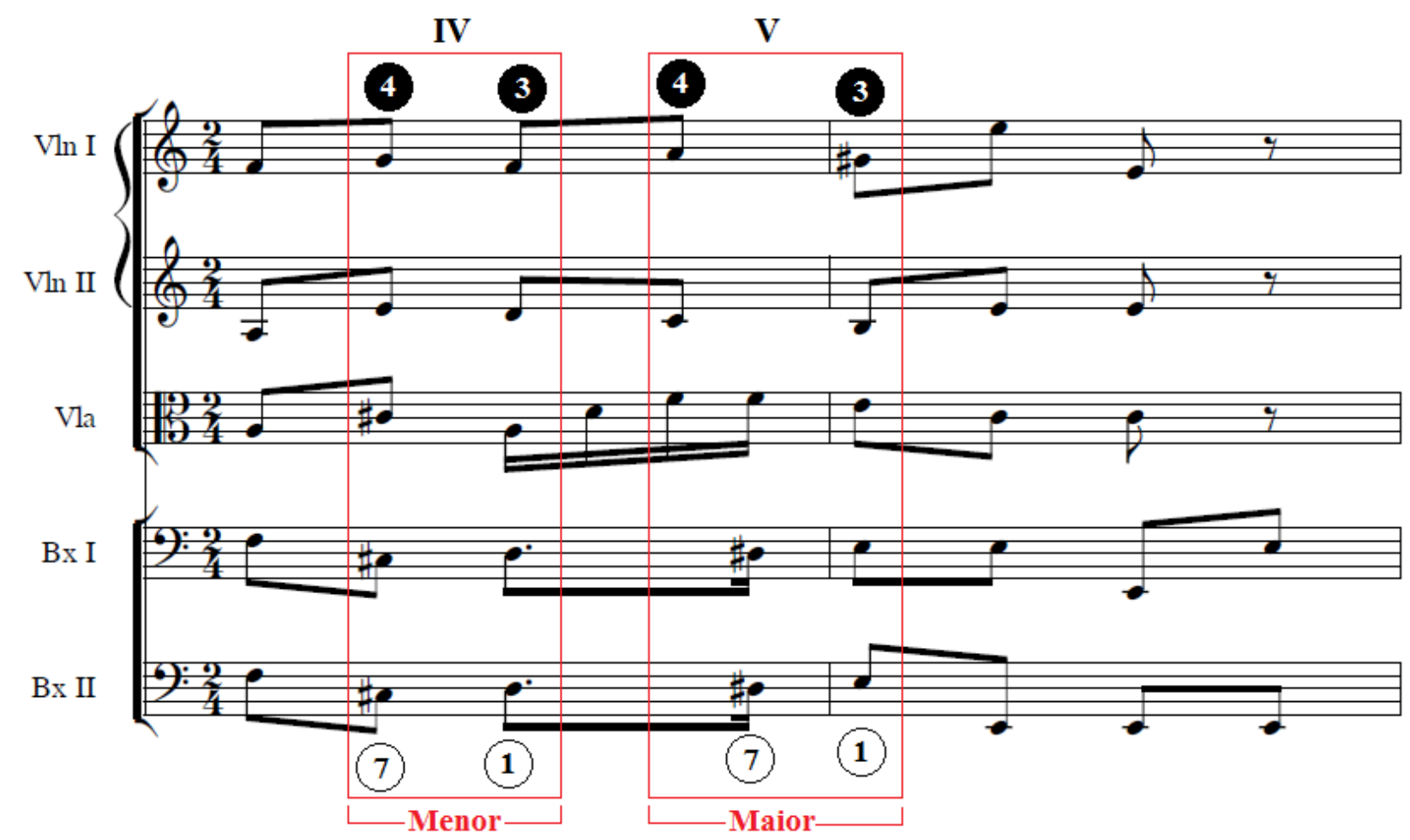

Exemplo 6 - Schemata Monte: Responsório IV, De profundis clamavi ad te, Domine, c. 45 e 46.

Terceira das mais importantes schematae, segundo Riepel (GJERDINGEN, 2007, p. 61), a Ponte configura-se, basicamente, em uma reiterada ênfase sobre os fatores que constituem o acorde de dominante. Como seu nome sugere, esta schemata tem como característica servir de elemento de ligação entre duas seções distintas, deslocando momentaneamente - e de forma mais sutil - a centralidade da tônica em prol da dominante. 


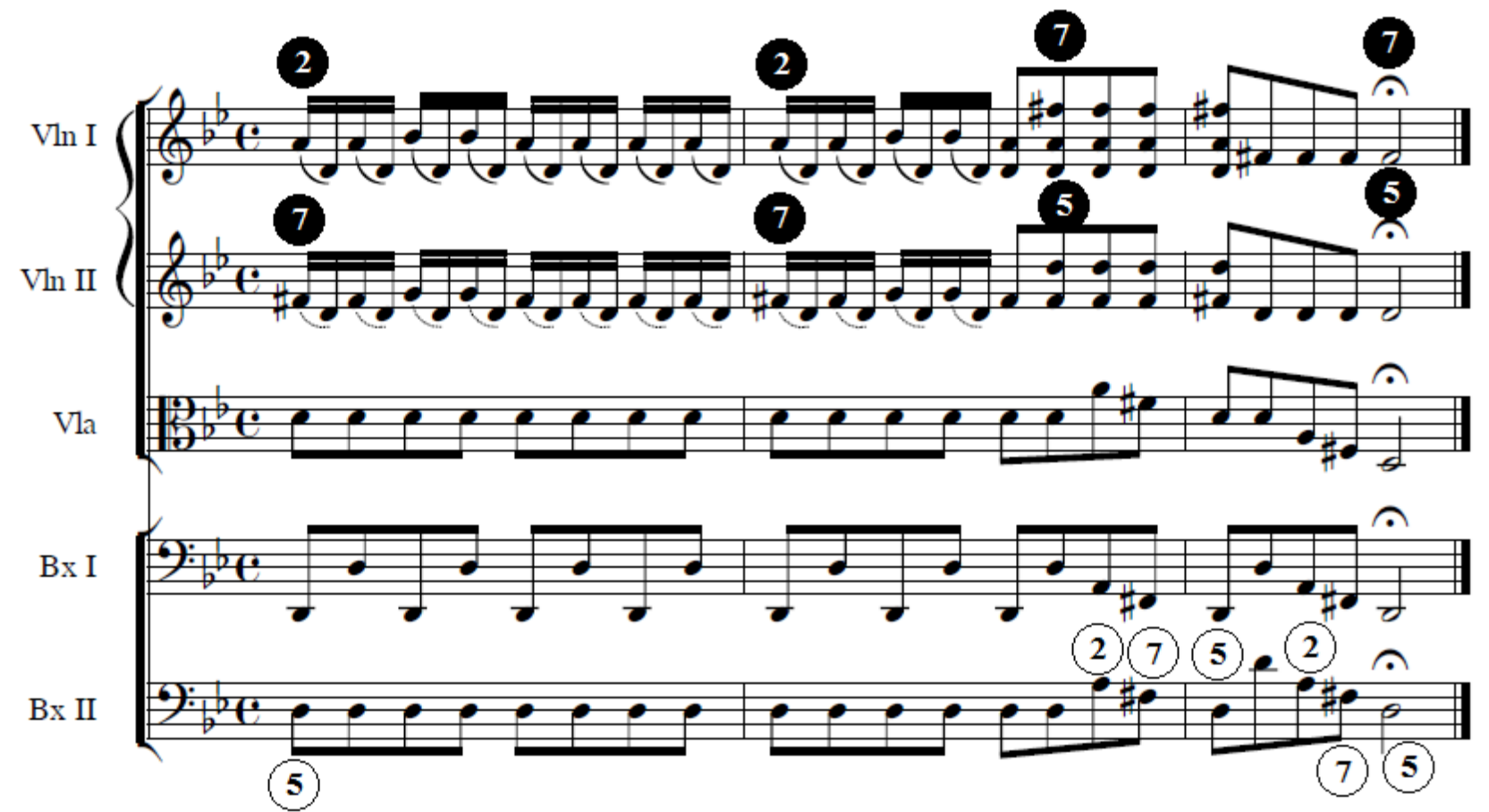

Exemplo 7 - Schemata Ponte: Responsório II, Qui Lazarum resuscitasti, c. 10-12.

Neste excerto, assinalado ao final do primeiro período do responso, no Responsório II, Castro Lobo utiliza esta schemata como um elo de ligação para o segundo período, contrastante ao andamento do primeiro; isto mostra o caráter articulado entre as seções do responsório. O pedal de dominante é estabelecido pelos baixos e a viola, enquanto os violinos I e II exploram os demais fatores do acorde.

De maneira idêntica à Ponte anterior, Castro Lobo aloca neste segundo exemplo a schemata ao final de uma seção, desta vez no verso do Responsório IV, dando à mesma o caráter de transição que prepara a chegada do repetendum (repetição do segundo período do responso) que encerra este responsório.

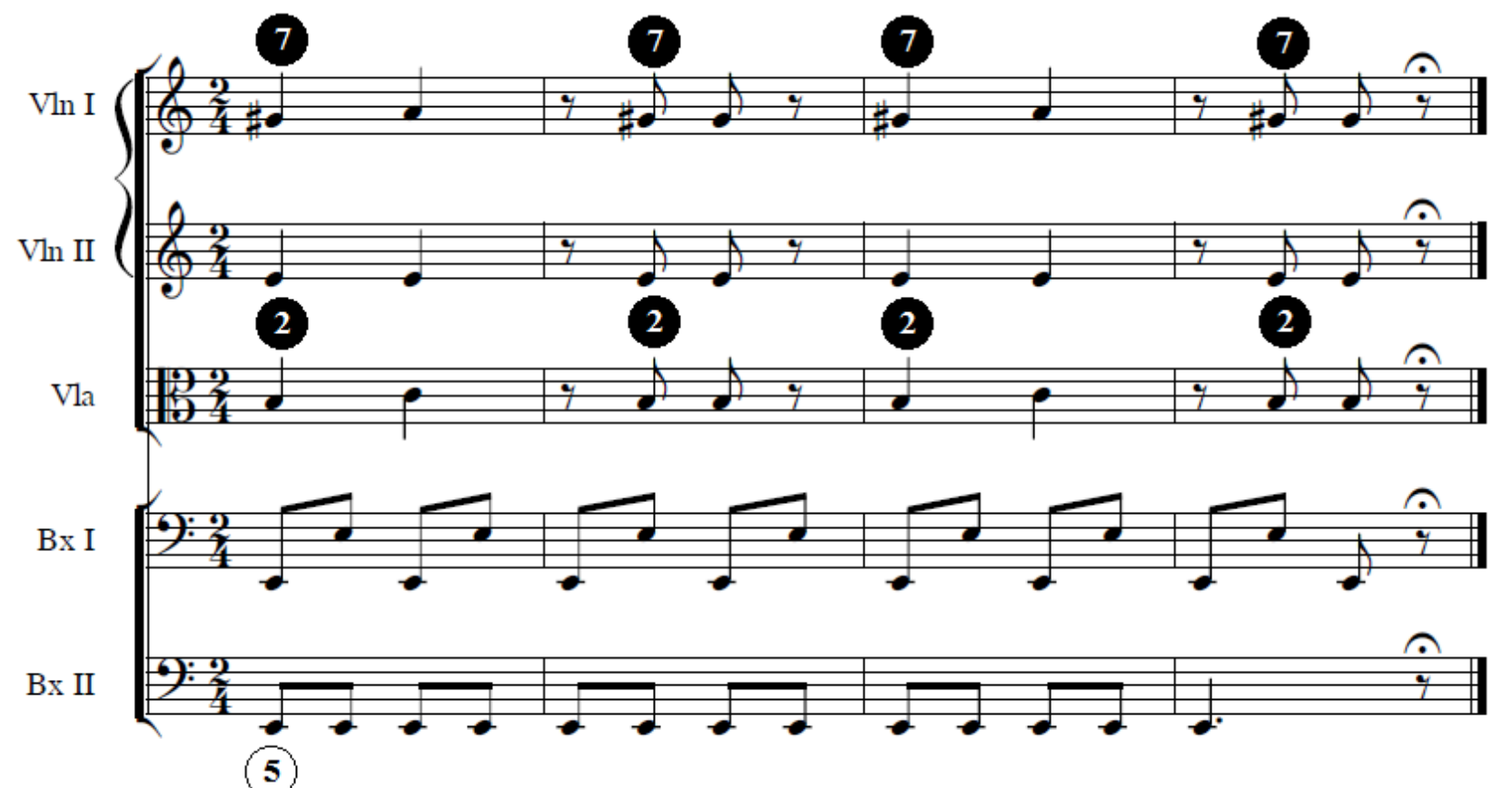

Exemplo 8 - Schemata Ponte: Responsório IV, De profundis clamavi ad te, Domine, c. 47-50. 
Gjerdingen mostrou ainda a existência de outros esquemas comuns para o recheio de elaborações estruturais. Aquela que leva o nome do célebre teórico Fedele Fenaroli (17301818) é uma das mais comuns da época, alcançando compositores diversos inclusive no meio do século XIX. Este esquema simula auditivamente uma imitação de vozes, embora o que aconteça na verdade seja uma dupla apresentação da sequência do baixo em 7-1-2-3, enquanto a voz em contraponto caminha de 5 a 4-3-1-7-1 com ou sem intercorrências.

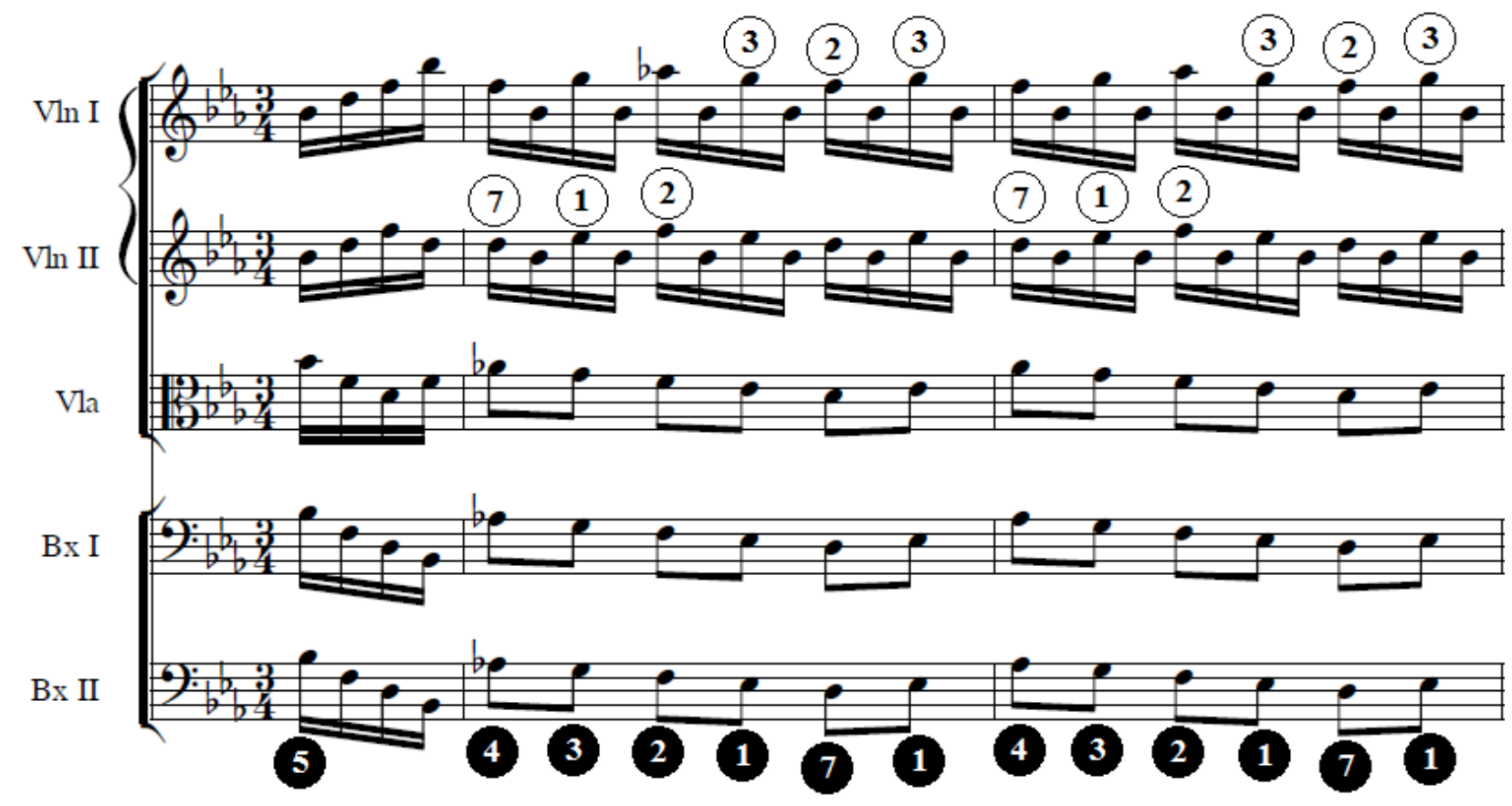

Exemplo 9 - Schemata Fenaroli: Responsório III, Domine, quando veneris judicare terram, c. 24 e 25.

A inversão de papéis (instrumentos do baixo com progressão de vozes melódicas e instrumentos melódicos conduzindo os graus do baixo) é comum também neste tipo de schemata. Aliás, sobre a ideia de imitação que este esquema sugere, Castro Lobo foi bastante hábil em elaborar a seguinte passagem:

(5)

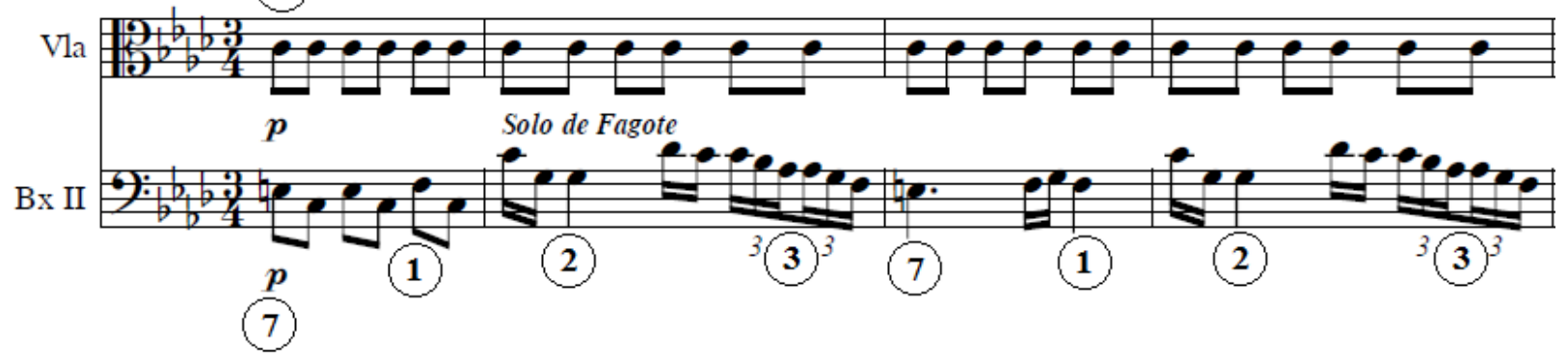

Exemplo 10 - Schemata Fenaroli: Responsório VI, Ne recorderis pecata mea, Domine, c. 13-16.

Castro Lobo fez uso deste esquema harmônico-contrapontístico em número razoável de vezes, em que o mesmo quase sempre precede um movimento cadencial localizado no final das seções responsoriais. Observável acima é que a melodia escolhida para o processo imitativo é uma citação ao solo de oboé e clarineta em dó presente na primeira parte da abertura da ópera L’italiana in Algeri, de Gioacchino Rossini (1792-1868).

Um dos esquemas preferidos dos autores da norma galante não passaria despercebido por Castro Lobo. Chamado de Meyer - em homenagem ao teórico Leonard Meyer (19182007), por ter sido este o primeiro a notar um arquétipo de mudança de notas -, este esque- 
ma tem contornos melódicos por trazer uma sequência semelhante ao grupeto: 1-2-7-1. Os graus característicos de sua melodia, 1-7-4-3, movimentam-se em sentido oposto àquele do baixo, compartilhando com as schematae da Fonte e do Monte a tendência convergente entre as linhas inferiores e superiores, assim como o mesmo par de eventos finais 7-1 e 4-3. Isso possibilita que o Meyer integre em sua estruturação outras schematae e seja por elas incorporado, corroborando com a segunda característica apontada por Humelhart (1980 apud GJERDINGEN, 1988, p. ?) sobre as schematae, que afirma que "uma schemata pode estar embutida dentro da outra”. No entanto, segundo Gjerdingen (2007, p. 112), ao contrário da Fonte e do Monte que são tonalmente móveis, o Meyer é tonalmente estável, sendo utilizado para temas de maior importância.

Castro Lobo, no Responsório V, utiliza um Meyer como schemata de abertura:

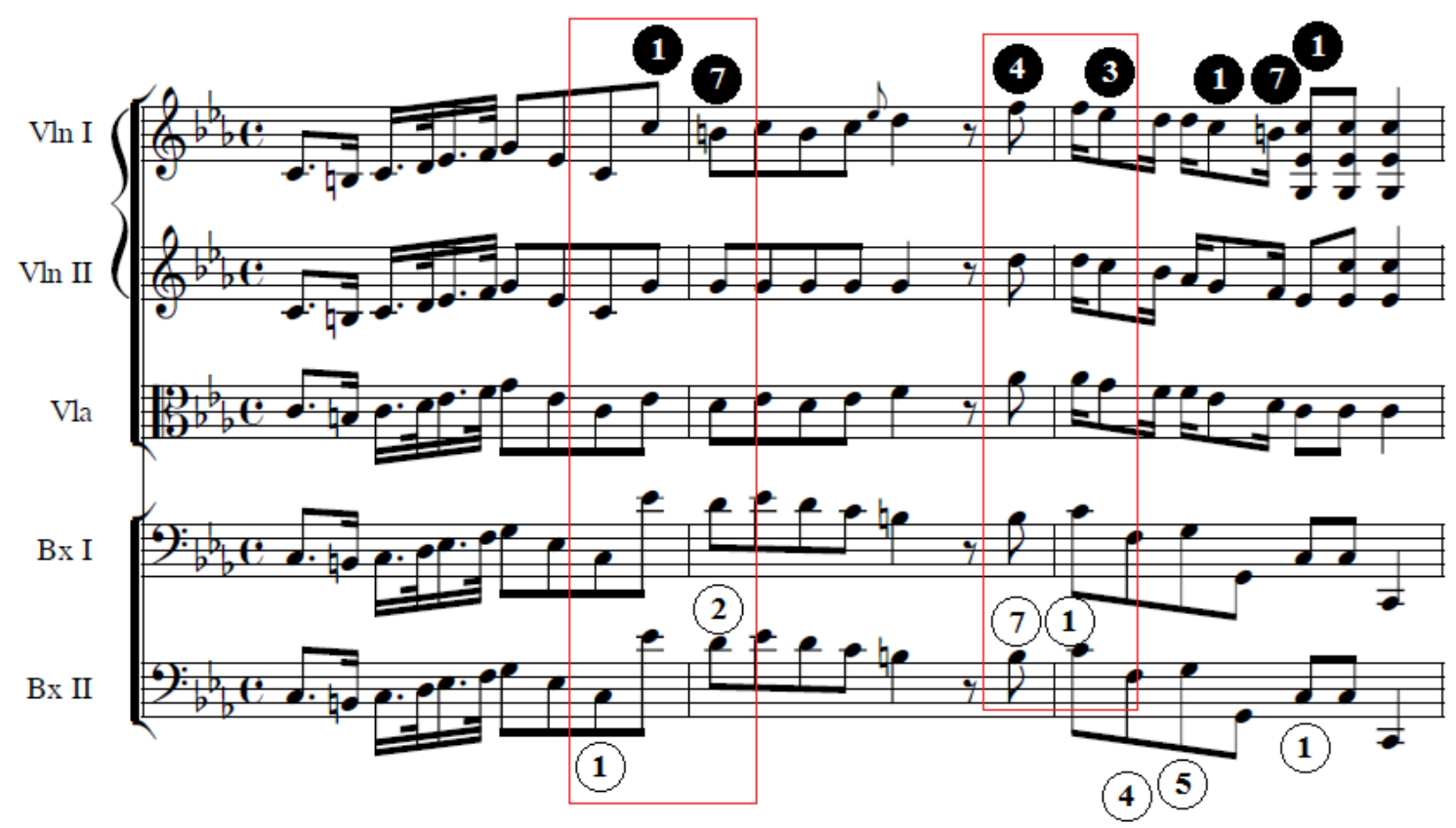

Exemplo 11 - Schemata Meyer: Responsório V, Hei mihi, Domine, c. 1-3.

E no Responsório III o esquema vai no meio da estrutura:

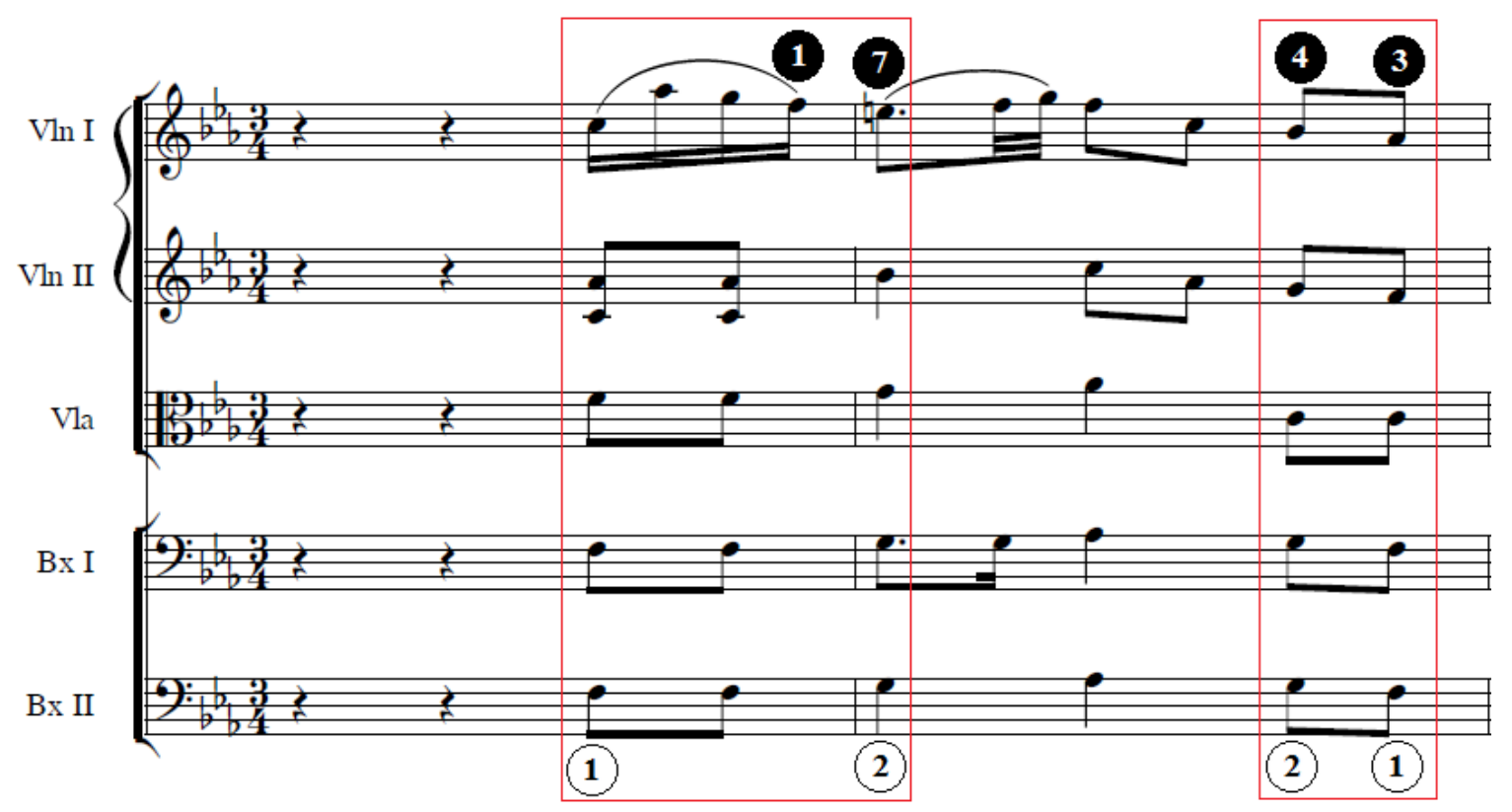

Exemplo 12 - Schemata Meyer: Responsório III, Domine, quando veneris judicare terram, c. 13 e 14. 
Ambas as elaborações coincidem, sendo que a mínima diferença que as separa é a cláusula vera de encerramento de frase, comum à época e mantida na teoria oitocentista com outros nomes.

Castro Lobo usou ainda um esquema muito comum para a escrita sinfônica de autores clássicos. Leva o nome de Júpiter, segundo Gjerdingen (2007, p. 16), por estar presente na última sinfonia de Mozart. A melodia vê sempre a ocorrência dos graus 1-2-4-3 sobre baixo e 1-7-7-1 ou variantes.

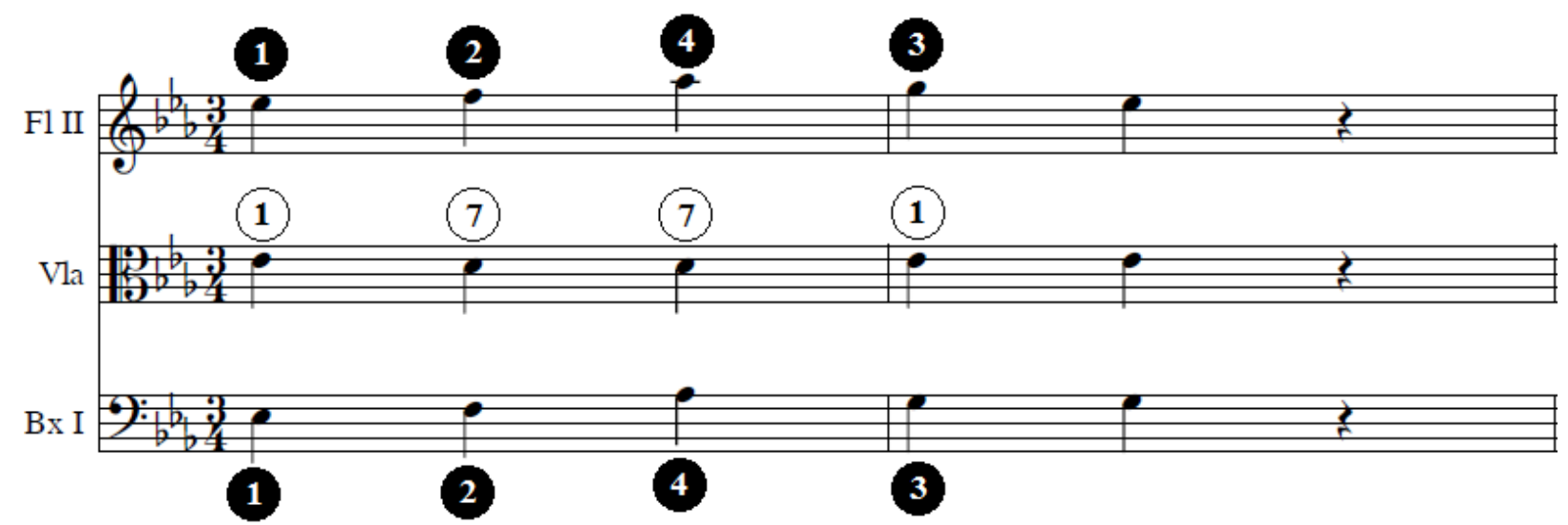

Exemplo 13 - Schemata Jupiter: Responsório III, Domine, quando veneris judicare terram, c. 1 e 2.

O efeito brilhante do esquema pode ter inibido o autor mineiro no uso mais repetido da formulação. Se o significado intrínseco da formulação pode ser associado ao argumento da obra em trechos específicos, a schemata da Pastorella (GJERDINGEN, 2007) encontrou no trecho abaixo um momento oportunamente curioso na exposição do baixo solista sobre a ressurreição de Lázaro:

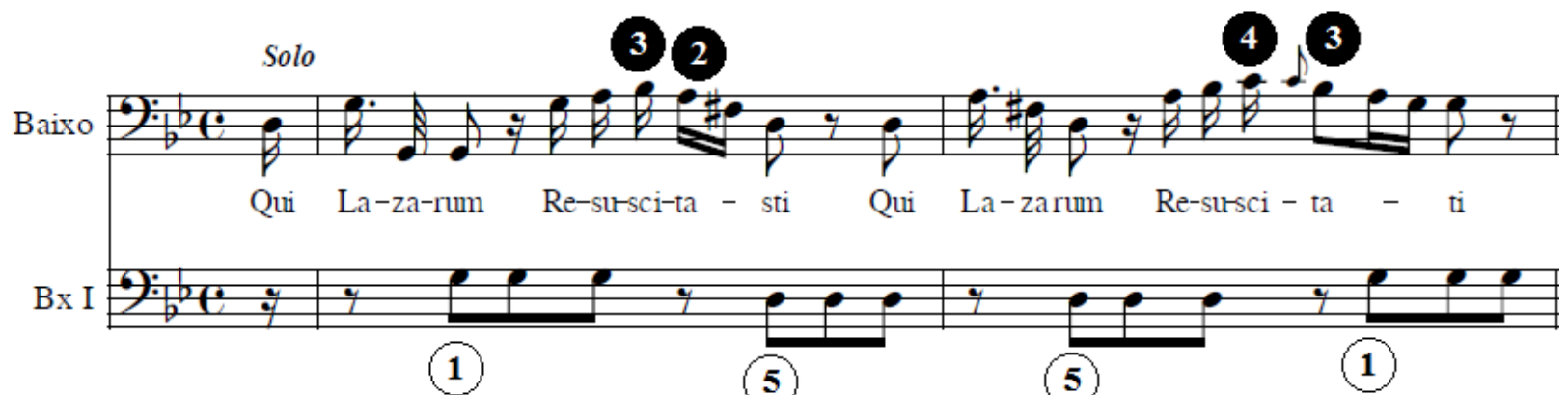

Exemplo 14 - Schemata Pastorella: Responsório II, Qui Lazarum Resuscitasti, c. 6 e 7.

Identificada por John A. Rice (2014), a schemata, ou procedimento harmônico, que ele denominou Heartz (em homenagem ao musicólogo norte-americano Daniel Heartz [*1928]), tem sua harmonia de subdominante sobre um pedal de tônica (RICE, 2014, p. 1), e aparentemente uma tendência a ser associada com aspectos de doçura ou ternura (veem-se por vezes as expressões como dolce etc), referência talvez à suavidade da subdominante em segunda inversão (6/4).

No excerto acima, assinalado no início do verso (Responsório I), podemos verificar, além do pedal sobre a tônica, o contorno melódico sobre os graus 5 e 6 que caracteriza a voz superior da schemata. Estruturalmente, o Heartz dispõe, segundo Rice (2014, p. 6), de no mínimo três eventos, sendo construídos sobre os mesmos, respectivamente, os acordes de tônica em estado fundamental (5/3), o acorde de subdominante em segunda inversão (6/4) e um retorno ao primeiro acorde. 
Uma segunda ocorrência deste modelo - com um número maior de eventos - se dá no início do segundo verso, no Responsório VI, conformando-se às características supracitadas.

5

6

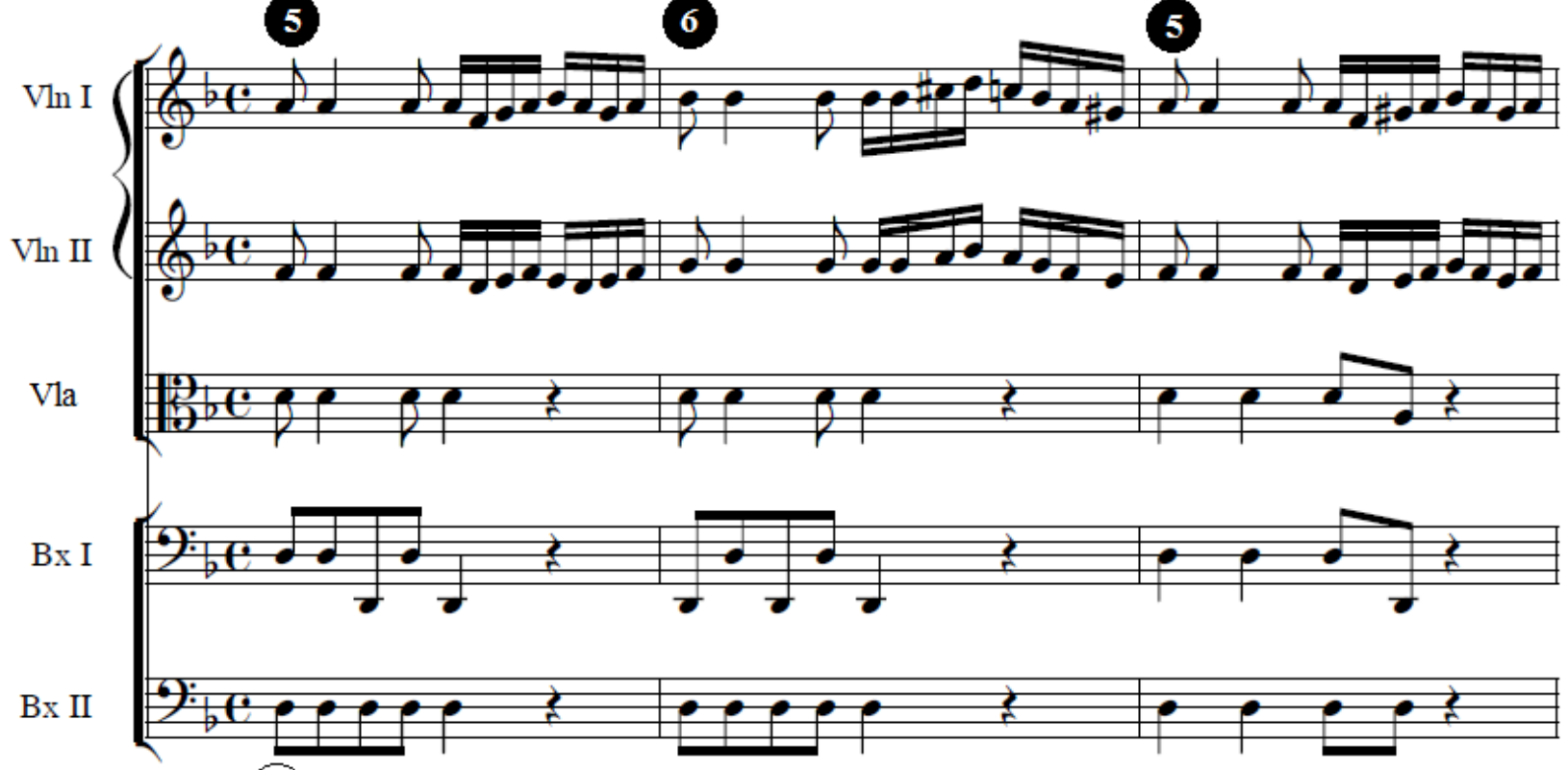

(1)

Exemplo 15 - Schemata Heartz: Responsório I, Quem visurum ego ipse, c. 47-49.

Observa-se, também, que o compositor optou por colocá-la em um movimento lento, cujo caráter nesta seção do responsório sugere algo lânguido e sereno, atribuível às passagens que contém o acorde de subdominante em segunda inversão, mas também por causa da tonalidade de Lá bemol Maior que tem tal força afetiva.

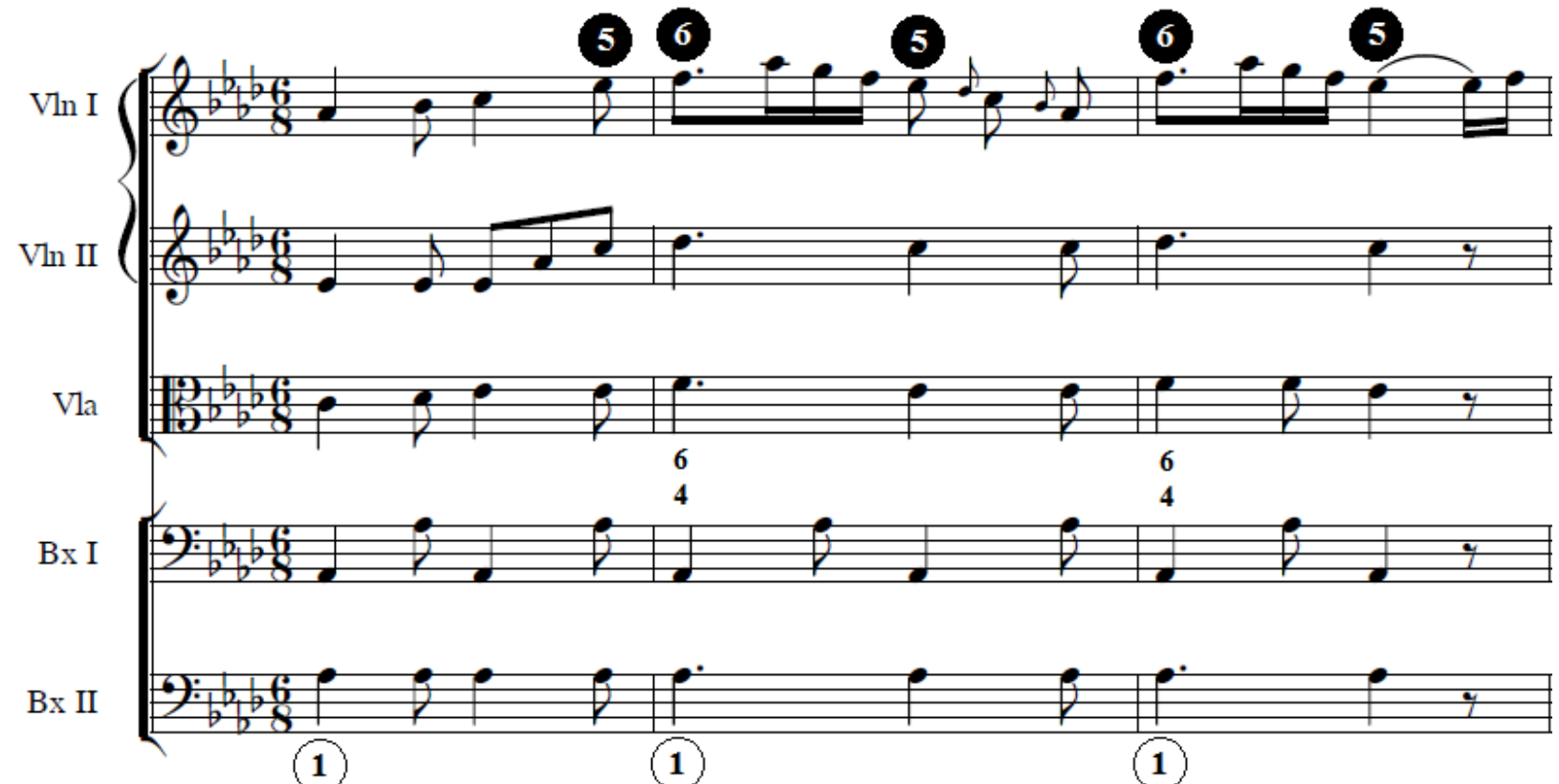

Exemplo 16 - Schemata Heartz: Responsório VI, Requiem æternam, c. 51-53.

Rice (2016) contribuiu recentemente com mais uma schemata significativa: Lully; assim batizada em homenagem ao compositor italiano, naturalizado francês, Jean Baptiste Lully (1632-1687). Igualmente à Romanesca, Do-Ré-Mi, entre outras, é costumeiramente 
utilizada em aberturas das obras do período Galante, embora já existisse no século XVII e ainda tenha sido usada pelos autores clássicos (RICE, 2016, p. 5). Assim como outras schematae, Rice (2016) também considera Lully um padrão característico do baixo; este faz o movimento 1-1-7-1 ao longo de 3 eventos, ou seja, a melodia se apoia numa sequência 1-3-5 no primeiro evento, 4-2 no segundo e finalizando em 1-3 no terceiro.

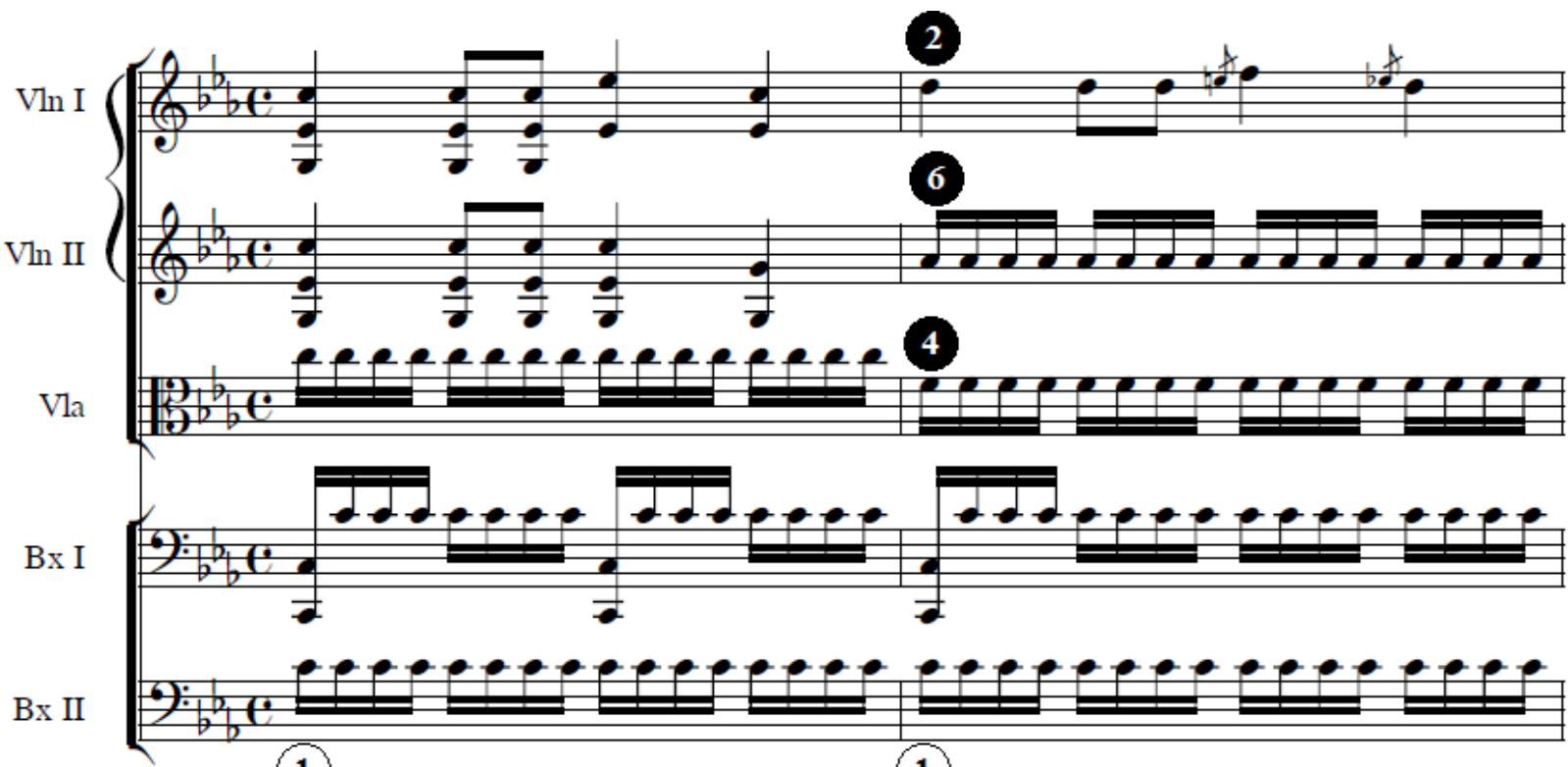

(1)

(1)

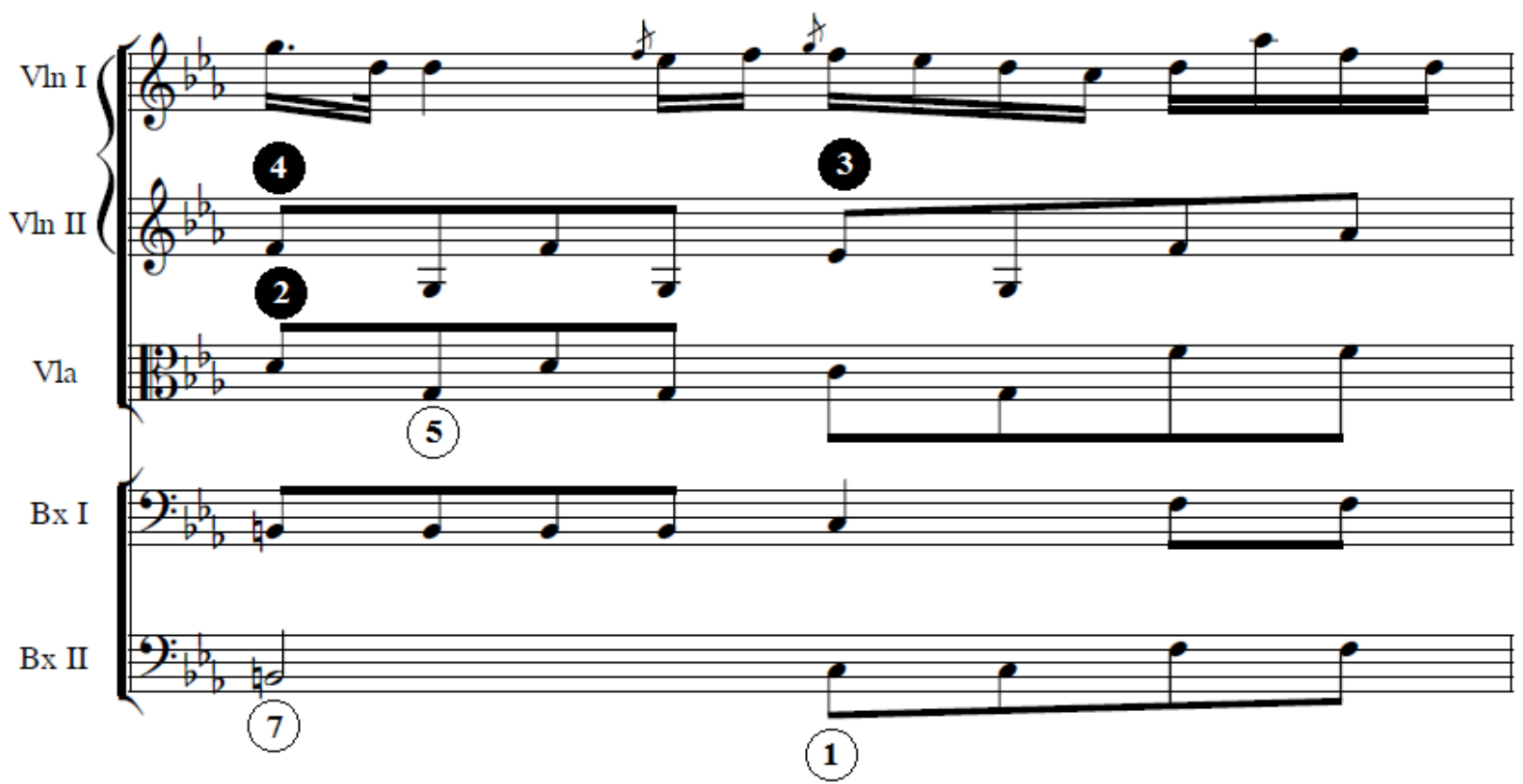

Exemplo 17 - Schemata Lully: Responsório V, Hei mihi! Domine, c. 8-10.

Castro Lobo, como inúmeras vezes se pode flagrar, parece ter feito a escolha do esquema em consonância com o texto, pois incide sobre o responso de texto Quid faciam miser? Ubi fugiam ${ }^{5}$ [...], iniciado após uma seção a solo endereçada à voz de contralto, em que estão coro e orquestra.

Também foi muito recentemente descrita a schemata que leva o nome de Volta (MITCHELL, 2016), em que a curva melódica parte de quarta aumentada indo ao quinto grau, mas retornando daí ao 4-3, tudo sob baixo 1-7-7-1, sendo admissíveis as variantes truncadas em que algum dos graus internos é eliminado. 
Uma dessas variantes truncadas pode ser encontrada no Responsório III:

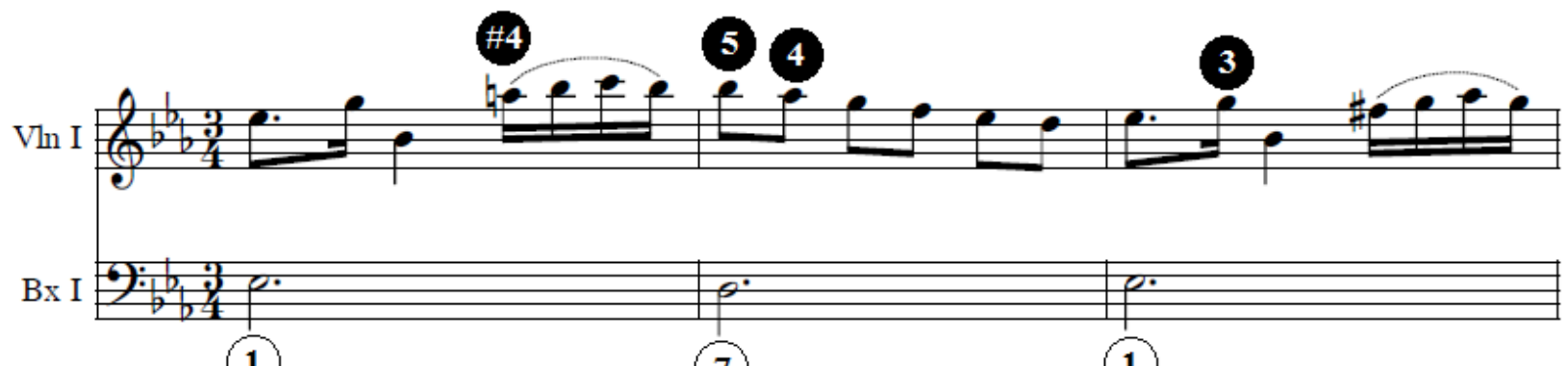

(1)

(7)

(1)

Exemplo 18 - Schemata Volta: Responsório III, Commisa mea pavesco, c. 60-62.

A última schemata aqui abordada é certamente a mais adequada ao tema dos responsórios e a qual se implica uma qualidade retórica indissociável. Vasili Byros (2014, p. 381-414), partindo de um estudo acerca da sinfonia Eroica, Op. 55 (1803-4), de Beethoven (1770-1827), identifica um padrão harmônico-contrapontístico que é um amálgama sintático-semântico musical, ou seja, uma mescla entre schemata e tópicas, ${ }^{6}$ batizando-o de Le-Sol-Fi-Sol por conta de suas particularidades intervalares: b6-5-\#4-5, ao que corresponde um contraponto de 1 e 3 na voz superior.

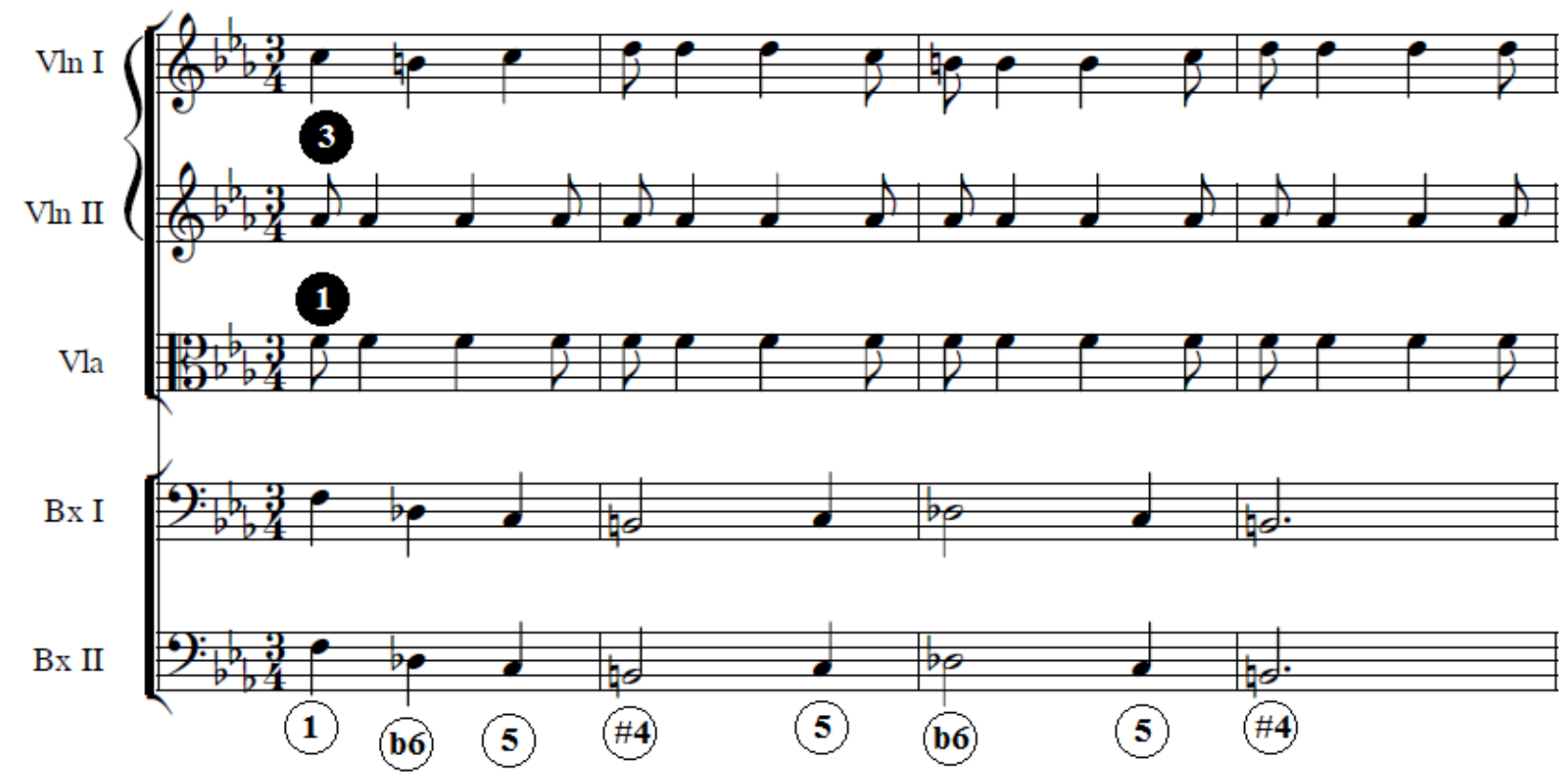

Exemplo 19 - Schemata Le-Sol-Fi-Sol: Responsório V, Miserere mei, c. 29-32.

Byros examinou volume significativo de partituras, três milhares, respectivas ao período 1720-1840 e encontrou 550 exemplos do uso desta elaboração com pico de incidência para a década de 1790 (BYROS, 2014). Advinda do conhecido e teorizado orgelpunkt, este esquema contrapontístico foi usado em associação com a tópica de ombra nas tonalidades de dó menor e ré menor ou suas relativas diretas. ${ }^{7}$ Mais do que apenas a representação do sombrio e sobrenatural, le-sol-fi-sol é a representação do funéreo, da mortalidade e todo o contorno dramático que isso envolve. Byros conclui que se trata de um caso que os linguistas chamam de colostrução, ou seja, quando um termo tem forte grau de atração em uma construção, elaboração que por si já encerra um argumento (BYROS, 2014). Assim sendo, o caráter fúnebre desta schemata foi adquirido desde o grau de dramaticidade que existia na 
sua base nascente, o orgelpunkt, associou-se com o argumento sobrenatural e sombrio (ombra) ao longo do século XVIII (em escolhas diversas que se verificam na obra de Bach, Mozart, Caldara, Lotti, Hasse, Heinichen etc.) até se consolidar como uma recorrente representação de valores ainda mais específicos.

Castro Lobo parecia absolutamente consciente do uso de tal elaboração, que é, portanto, o impacto dramático. Valeu-se dessa schemata no quinto responsório fúnebre para incrementar a tensão harmônica, gerada pela oscilação cromática do baixo, em que, no decorrer de sua apresentação, não se tem certeza do tipo de tratamento que o autor dará à sua sequência. Após isso, frustrando a expectativa quanto ao estabelecimento da dominante no último evento da schemata, o autor mineiro modula de Fá menor (tonalidade do excerto) para Mi bemol maior (relativa maior de Dó menor, com pedal em Si bemol), evitando, assim, deslocar o centro tonal deste responsório (em Dó menor) para uma nova tonalidade.

Antes de qualquer conclusão, deve-se ainda alertar para o fato de que uma grande quantidade de cláusulas e cadências descritas por Gjerdingen (Passo indietro, comma, cadência dupla, cadência de engano etc), umas já incorporadas à teoria tonal que se desenvolveu nos manuais do século XIX e outras agora observadas no estudo de schematae, e que aqui não foram mencionadas, foram encontradas em um exame mais detido dos Seis Responsórios Fúnebres de Castro Lobo. Deve-se também reforçar que estes exemplos pontuais foram aqui escolhidos para destacar variedade de procedimentos; as schematae descritas ocorrem muitas vezes e a apresentação de todas elas excederia os limites deste artigo e o seu próprio propósito.

\section{Conclusão}

Assim, os achados de tantos esquemas de contraponto nesta obra de Castro Lobo permitem algumas conclusões. Primeiramente a de que os aspectos compositivos em curso na Europa ocidental estiveram em uso no Brasil do Antigo Regime. Consequentemente a isto, a de que os autores pátrios dominaram não apenas recursos técnicos, mas conceitos complexos de ordem retórica, conforme algumas construções esquemáticas aqui apontam.

O estudo destes modelos compositivos segundo a teoria adequada (e não a de manuais posteriores), ainda que hoje precise ser reorganizada - haja visto que no século XVIII e parte do XIX este conhecimento se exercia num domínio teórico-prático, muitas vezes sem um método formal de transmissão -, vai revelando não apenas processos mais lógicos de criação musical, como revela ainda uma outra matriz de orientação elaborativa, diferente do cânone anglo-saxão que se conhece. O estudo e a eventual análise sistemática do patrimônio musical pátrio devem revelar ainda novos patamares de desenvolvimento local destes aspectos, para que enfim a obra musical do Brasil deste período alcance a dimensão e o reconhecimento que ainda carece.

A larga utilização dos esquemas de contraponto, as schematae, no sentido usado por Robert Gjerdingen, assim como a variedade de modelos a que Castro Lobo recorreu, evidenciados neste artigo, é prova inconteste da metodologia de origem nos conservatórios napolitanos em voga no século XVIII. Os músicos portugueses que estudaram em Nápoles e a existência de cadernos de partimento e solfeggio em Portugal deixam de ser assim mera hipótese de associação para saber o que se passou em solo brasileiro no tocante a tais assuntos. Somente a continuidade dos escritos em que se mostrem claramente pela dimensão analítica, não necessariamente adstrita a esquemas de contraponto, mas a um conjunto de procedimentos, pode mostrar em que nível tais influências, que percorreram grande parte da Europa, foram aplicadas no Brasil do Antigo Regime, 
e mesmo além. Quanto mais trabalhos neste sentido puderem se somar a esta iniciativa, mais firmemente podemos asseverar o que hoje tem sido mera especulação. Se não fundada em procedimentos científicos que devem obedecer a requisitos criteriosos de verificação devidamente publicados, tudo não passa de mera especulação e não estabelece convicção sobre como se desenvolveu importante momento da história da música no Brasil.

\section{Notas}

1 Caderno de exercícios de baixo contínuo contendo diversas elaborações de baixos, de autoria igualmente diversa, para serem realizados de maneira a desenvolver a habilidade do praticante. Neles se observam a origem popular de algumas destas linhas, assim como cláusulas, cadências e formulações de contraponto que, se tornando mais em uso, adquiriram força de norma de estruturação.

2 "O termo galante foi bastante utilizado no século XVIII. Referia-se amplamente à reunião de tratos, atitudes e maneiras associadas à nobreza culta” (GJERDINGEN, 2007, p. 5, tradução nossa).

3 A edição feita por Carlos Alberto Figueiredo para a coleção do Patrimônio Musical Arquivístico Mineiro em 2001 foi a que serviu aos nossos apontamentos.

4 Schemata, batizada por Gjerdingen em homenagem ao músico e pedagogo alemão Johann Jacob Prinner (16241694).

5 “[...] Miserável de mim, que farei? Para onde fugirei?".

6 Para maiores detalhes sobre a Teoria das Tópicas ver MIRKA, Danuta. The Oxford Handbook of Topics. New York; Oxford/OUP, 2014. Aqui, nos deteremos apenas sobre o aspecto sintático-musical, ou seja, sobre os elementos internos que constituem esta schemata.

7 A tópica é descrita amplamente por Clive McCleland (2012).

\section{Referências}

BYROS, Vasili. Topics and harmonic schemata: a case from Beethoven. In: The Oxford Handbook of Topics. New York: Oxford/OUP, 2014. p. 381-414.

CASTAGNA, Paulo et al. Acervo da Música Brasileira: música fúnebre. Belo Horizonte: Fundação Cultural e Educacional da Arquidiocese de Mariana, 2003. v. IX.

. João de Deus de Castro Lobo: vida e obra. Programa Manhã Cultura. Entrevista concedida a Ligiana Costa. São Paulo: Rádio Cultura de São Paulo, 20 abr. 2013. Disponível em: < https://www.youtube.com/watch?v=npVOPoXP6Qc >. Acesso em: 21 jul. 2017.

. Produção musical e atuação profissional de João de Deus de Castro Lobo (17941832): do desaparecimento de seus autógrafos à transmissão de sua música pelas redes sociais. Opus, Porto Alegre, v. 18, n. 1, p. 20-25, jun. 2012. Disponível em: <http://www. anppom.com.br/revista/index.php/opus/article/view/174>. Acesso em: 21 jul. 2017.

CASTAGNA, Paulo (Org.); MONTEIRO, Maurício Mário. João de Deus de Castro Lobo. Belo Horizonte: Patrimônio Arquivístico-Musical Mineiro, Secretaria de Estado de Cultura de Minas Gerais, 2011. v. 5. Disponível em: <https:/pt.scribd.com/document/322783694/Patrimonio-Arquivistico-Musical-Mineiro-v-5-Joao-de-Deus-de-Castro-Lobo-2011-pdf>. Acesso em: 21 jul. 2017.

CHRISTENSEN, Thomas. The work of music theory. Londres: Ashgate, 2014.

CHRISTENSEN, Thomas; BAKER, Nancy. A esthetic and the art of musical composition in german enlightenment: elected writings of Johann Georg Sulzer and Heinrich Koch. Cambridge: Cambridge University Press, 1995. (2007 paperback).

DONINGTON, Robert. The interpretation of early music. London: Faber, 1991. 
GJERDINGEN, Robert. A classic turn of phrase: music and the psychology of convention. Philadelphia: University of Pennsylvania Press, 1988.

. A musical schema: structure and style change 1720-1900. F?. 1984. Tese (Doutorado em ?) - Universidade da Pensilvânia, Filadélfia, 1984.

. Music in the galant style. New York: Oxford University Press, 2007.

LOBO, João de Deus de Castro. Seis responsórios fúnebres. In: Música Fúnebre. Coordenação Musicológica: Paulo Castanha/Coordenação editorial: Carlos Alberto Figueiredo. Belo Horizonte: Fundação Cultural e Educacional da Arquidiocese de Mariana, 2003.

LOPEZ-CANO, Ruben. Musica y retorica en el barroco. Barcelona: Amalgama, 2012.

MCCLELAND, Clive. Ombra: supernatural music in the eighteenth century. Plymouth: Lexington Books, 2012.

MIRKA, Danuta. The Oxford handbook of topics. New York: Oxford/OUP, 2014.

MITCHELL, Nate. The volta: a galant gesture of culmination. Philadelphia: Music Theory Society of the Mid-Atlantic, 2016. Disponível em: <societymusictheory.org/files/2017_handouts/mitchell.pdf>. Acesso em: 22 maio. 2017.

RICE, John. Adding to the galant schematicon: The Lully. Kassel: Bärenreiter, Mozart-Jahrbuch, 2015. Disponível em: <http://www.academia.edu/7783771/Adding_to_the_Galant_Schematicon_The_Lully>. Acesso em: 18 maio. 2017.

. The Heartz: a galant schema from Corelli to Mozart. Music Theory Spectrum 37. 2014. Disponível em: <http:/mts.oxfordjournals.org/content/early/2014/09/24/mts.mtu016>. Acesso em: 24 maio. 2017.

TRILHA NETO, Mário Marques. Teoria e prática do baixo contínuo em Portugal (1735-1820). 419 f. 2011. Tese (Doutorado em Música) - Departamento de Comunicação e Arte da Universidade de Aveiro, Universidade de Aveiro, Aveiro, 2011.

VAN TOUR, Peter. Counterpoint and partimento: methods of teaching composition late eighteenth century Naples. Uppsala: Acta Universitatis Upsaliensis. Studia Musicologica Upsaliensia, Nova Series 25, 2015.

. The 189 partimento of Nicola Sala: complete edition with critical commentary. Uppsala: Acta Universitatis Upsaliensis, 2017. 3 v.

Márcio Leonel Farias Reis Páscoa: Doutor em Ciências Musicais pela Universidade de Coimbra. Professor da Universidade do Estado do Amazonas. Membro permanente do Programa de Pós-Graduação em Letras e Artes (PPGLA-UEA). Coordenador do Laboratório de Musicologia e História Cultural da UEA. Investigador da Universidade Nova de Lisboa, no Centro de Estudos em Estética e Sociologia Musical (CESEM) e membro do Conselho Científico do Núcleo Caravelas de Estudos Luso-Brasileiros da mesma instituição. É um dos coeditores da História Temática da Música em Portugal e no Brasil.

Guilherme Aleixo da Silva Monteiro: Mestrando do Programa de Pós-Graduação em Letras e Artes (PPGLA) da Universidade do Estado do Amazonas. 